\title{
e-Governance Model to ease the Management of Revenue Court Cases
}

\author{
Jitender Singh, Bright Keswani, Ashish Chaturvedi
}

\begin{abstract}
In the current scenario, management of land records as well as peace, both have been on the backburner. For the raging topics like this, Revenue courts adjudicate such matters especially related to matters of tenancy, land disputes, removal of encroachments, partition of land, transfer of land and the list goes on. Earlier there was no such system which can tell the details about the number of disposed and pending cases from the level of District Courts to Supreme Court. There was not any platform for revenue cases but web portal has revolved the whole criteria and made such cases easy to deal with.Awareness, unfortunately a hindrance in the path of digital world but with quality of education this can be improved. Various steps are definitely taken in this direction to make it work in a smooth way. This paper has worked upon the root of the problem and the ways to penetrate it.
\end{abstract}

Keywords: E-Governance; Revenue Court; Saral; Justice Delivery System

\section{INRODUCTION}

\subsection{Overview of Revenue Courts}

Revenue courts are the courts that deal with the cases of Land Revenue in the respective state. These courts arbitrate into matters related to Land Revenues and, by denotation, into matters of the occupancy of property etc. under a lease, or by paying rent and boundaries of agricultural land.

When it comes to discussing Revenue Court in India then the highest revenue court in the district is the Board of Revenue. The courts of Commissioners, Tehsildar and Assistant Tehsildars, Collectors comes under it. Then the main purpose of Board of Revenue is to hear the final appeals against all the lower revenue Courts that comes under it.

All over the world, Revenue Courts are known for thedispute that exists over land like it deals with matters such as nonpayment of land revenue, land ceilings, tenancy laws, agriculturists and peasants disputes, etc. So the cases that come under one of these categories are referred as Revenue Court Cases.

Geographically, the owner of all the land that falls in the boundary of a particular state is assumed to be the state itself. That's why, state is convinced of one's own righteousness to charge a rent or tax on use of that, no matter if it is freehold in the name of the owner or leased. Depending on the nature of the land, the State fixes the Land Rent or Land Revenue. The cases that seem simpler to deal with are actually the hassle ones. Handling Revenue Court Cases have never been the

Revised Manuscript Received on July 22, 2019.

Jitender Singh, Research Scholar, Department of Computer Science \& Engineering, Suresh Gyan Vihar University, Jaipur, India

Dr. Bright Keswani, Professor, Computer Science, Department of Computer Science \& Engineering, Suresh Gyan Vihar University, Jaipur, India

Dr. Ashish Chaturvedi, Professor, Computer Science, Calorx Teachers' University Ahmedabad, India easy task. So in this report, we will discuss how e-services has changed the approach of department centric system to citizen centric system and from process based system to a service based system. The difficulties faced by the Revenue Courts as well as the common man and their interoperable solutions are some of the important topics that are to be discussed. Case studies on various projects is the practical way to look how online web applications of Land Records, Revenue Court Cases, Bhu-Naksha (Digitized recording Succession or Varasat) and Anti-Bhu-Mafia Portal (for action against land grabbers) have been integrated on a single platform .

\subsection{Difficulty Faced by Revenue Courts}

Encroachment on Government Land: An audit disclosed that there was not any particular system of handling database of Government land, despite identification of cases of encroachment over an area of 1.78 lakh square meter, these were not entered in the registers of encroachments i.e. "Dayra registers" [2]. Furthermore, in non-existence of separate penalty provision, the Tehsildars imposed penalty on the basis of rent applicable for agricultural land on 3,101 trespassers who had encroached upon 30.77 lakh square meter of Government land for commercial, housing, industrial and brick kiln purpose. [2] No Vigilance and Encroachment Prevention cell existed to restraint the encroachments.

- Data entry and saught of data: After looking at the size of the State like U.P., the idea is clear that the volume and size of the data involved is more, the data entry and its reconciliation with the manual records was truly a tough challenge. And to deal with this general problem, extra work has to be done with enthusiastic leadership at District and Tehsil level in addition to their regular duties. Active participation of the entire Revenue Administration in the state is required because a continuous push from the top is necessary. Another important challenge was the resistance and obstacles created by the vested interests that used to exploit the old corruption prone manual system which was needed to solve.

- Maintenance of manual Records : Revenue courts are responsible for resolving cases related to land like land division, correction of land records or updation, rights regarding land ownership, mutation of properties, partition of family property among members, auction of land etc. Handling cases manually at such vast level is definitely not an easy task. 
- In the current scenario, numbers of revenue cases are skyrocketing so maintaining manual court records is not a practical solution and hindrance in solving cases in the given timeframe. The problem of pendency in courts is not peculiar across the courts in the country whether it's Revenue Court or Civil Court.

- Poor Management: Most of the courts do not even have proper resources so that they can look after all the cases that are being filed in the meantime. Some courts are lacking in staff while others having problem in dealing with the pending cases.

\subsection{Difficulties Faced by Common People}

Incompetent procedures: Over time, land management and peace keeping have been deferred irrespective of their extreme need. The number of land disputes and revenue cases are sky-high, adding to the misery of the already distressed farmers. But the procedures of solving such cases are oppositely slothful. Sometime even result in suicidal attempts done by the farmers especially.

- Lack of platforms: Unlike the National Judicial Data Grid that gives real and exact details about the number of inclined and pending cases from the level of District Courts to Supreme Court, there is no such base for revenue cases. In fact in some states, the chief secretary has to count on the data shared by the same district collector who may have bestowed to increasing pendency. A common man has to travel to various places just to get his case solved and some finds it difficult by accepting that government works take time so it's better to give up. And all this happens because of the lack of platforms for the hearings of every other person.

- Delay for the next hearing: The numbers of pending cases in each revenue courts have always been this difficult to count and to resolve each of them. This arise another issue, that is, delay in the next hearing date which creates problems in victim's personal life as no one knows that if the particular land might be the only source of income for which he has been fighting from days or months or years. Additionally, the status of disposed cases is also nonintuitive, that means waiting is the only solution that people can afford to get their case resolved in its mean time.

- Levy and collection of stamp duty and registration fee : A Judicial examination reveals that Meetings of District Level Committee( DLC) were not being conducted properly, no mentioned criteria was taken up for revising the DLC rates which resulted in the false reflection of actual market rates and rates at which properties were auctioned by urban local organizations. Site scrutinizes were not being conducted responsibly and hence were not efficient in accomplishing the intended purpose.

- Manual Records: The management of manual records was predisposed to errors because their lack of transparency and accessibility resulted in torment of common public including farmers as well. Clearly, the management and maintenance of land records was gradual, error prone and inefficacious. Due to its sheer volume and potency, it was almost impossible to interlink and correlate it with other cases and moreover, it was also extremely difficult to analyse each of the records which not only requires time but also precision to avoid erroneous results.

\section{OVERVIEW OF REVENUE COURT CASES' SOLUTIONS}

Common man has always been suffering the most while fighting for his cases and it is all because of the poor old system of dealing with revenue cases. Emergence of egovernance with e-services has shown the government and public a glance to a better world (A digital world). Every other state is now improvising its system by transforming the traditional manual system into a digitalized court system .Entrance of internet in the judicial system sounds peculiar but aftereffects are amazingly efficient, reliable and satisfying. Recently, the functioning of the Revenue courts have digitized in majority of the states. States like Uttar Pradesh, Himachal Pradesh and Karnataka have already broke new ground in introducing online court management system. Also, states like Haryana, Bihar, Madhya Pradesh, and Telangana have shown drastic change by launching various schemes /services for the welfare and convenience of the citizens and some of them are:

- $\quad$ RCMS (Revenue Case Management System) in MP

- 'Digital Land' model in UP

- Digitization Revenue court system in Haryana and Punjab

- VAAD of UP

- RCCMS of Karnataka

- Digital India Land Records Modernization Programme (DILRMP) in Himachal Pradesh and Maharashtra

And the list goes on for so many other states also and it is to be discussed further that How by taking just few innovative steps can help in improving the whole system .

\section{SOLUTION}

To provide any of the service of Revenue court cases, click on the link 'Revenue Court Cases' has given in the transactional services area of home page of user. Figure-1 shows that screen. 
Table-1 Menu Items

\begin{tabular}{|c|c|}
\hline Menu Items & Home page of User \\
\hline - Home & Home page of User \\
\hline $\begin{array}{l}\text { - Application } \\
\text { Data Entry }\end{array}$ & $\begin{array}{l}\text { Data entry applicant details for } \\
\text { availing the service of } \\
\text { Revenue Court Cases }\end{array}$ \\
\hline $\begin{array}{l}\text { Modification of } \\
\text { Application }\end{array}$ & $\begin{array}{l}\text { Modify the applicant details for } \\
\text { availing the service of Revenue } \\
\text { court cases }\end{array}$ \\
\hline $\begin{array}{l}\text { - Search and } \\
\text { Print }\end{array}$ & $\begin{array}{l}\text { Search and print the details of } \\
\text { any of the service of Revenue } \\
\text { court } \\
\text { cases }\end{array}$ \\
\hline
\end{tabular}

Application Data Entry: This form is used to enter the application details for availing any of the services of Revenue court cases i.e. View case status or View cause list or View Judgment.

To open the form click on the Application Data Entry, following data entry screen will appear. The user can enter Citizen Registration No./CIDR Id(if he is registered in CIDR service). If he doesn't know the citizen registration no. then he can find that by clicking on 'Search Registration No.' and click 'GO' button, the form will be filled from CIDR database as shown below:

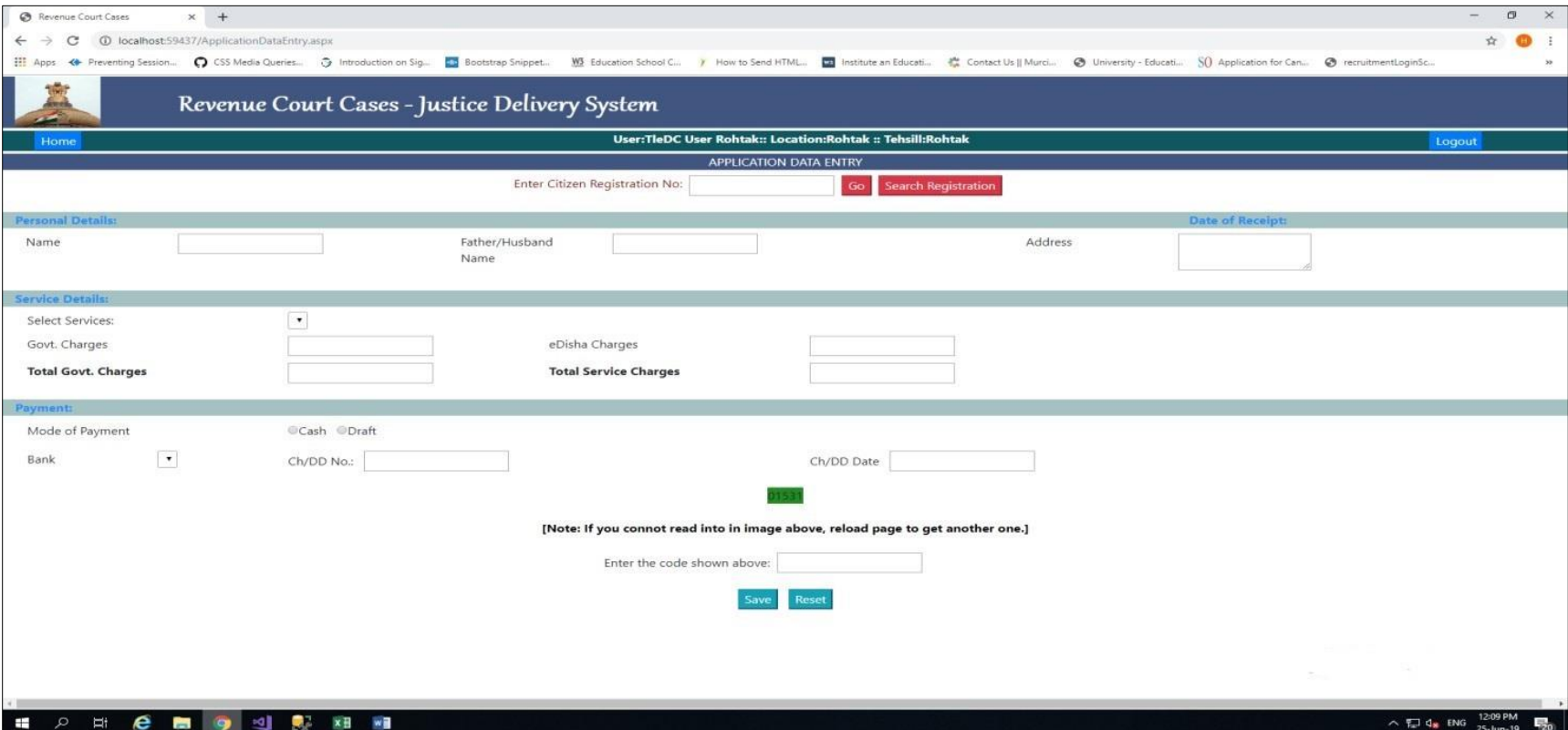

Figure-2 Application Data Entry 
The description of fields is given below:

\begin{tabular}{|c|c|}
\hline Field Name & Field Description \\
\hline Citizen Registration No. & $\begin{array}{lll}\text { Specify } & \text { Unique } & \text { citizen } \\
\text { registration id(CIDR ID) } & \end{array}$ \\
\hline Name & Name of applicant \\
\hline Father/Husband Name & $\begin{array}{l}\text { Name of Father or Husband of } \\
\text { applicant }\end{array}$ \\
\hline Address & Address of the applicant \\
\hline Select Service & $\begin{array}{l}\text { Name of the service i.e. View case } \\
\text { status or View cause list or View } \\
\text { judgment }\end{array}$ \\
\hline Total Govt. Charges & $\begin{array}{l}\text { Display of Government charges as } \\
\text { defined in 'Charges Master' for } \\
\text { the particular service, to be given } \\
\text { by the applicant }\end{array}$ \\
\hline Total Service Charges & $\begin{array}{l}\text { Display of service charges as } \\
\text { defined in 'Charges Master' for } \\
\text { the particular service, to be given } \\
\text { by the applicant }\end{array}$ \\
\hline Mode of Payment & $\begin{array}{l}\text { Cash or Draft.(Service Charges } \\
\text { will always be taken as cash) }\end{array}$ \\
\hline Bank & Select Bank from the list \\
\hline Cheque/DD No. & Cheque, Challan or DD number \\
\hline Cheque/DD date & Cheque, Challan or DD date \\
\hline Go button & $\begin{array}{l}\text { Click to fill data from CIDR } \\
\text { database }\end{array}$ \\
\hline Search Registration Button & $\begin{array}{l}\text { Click to search the data in CIDR } \\
\text { database }\end{array}$ \\
\hline Save Button & Click to save the data in database \\
\hline Reset Button & Click to initialize the fields \\
\hline
\end{tabular}

The user is then required to select the service and enter payment details. After that click 'Save' button and a message will appear and a receipt will be generated.

Modification of Application: This form is used to modify the application details whose status has not been changed yet i.e. after initial data entry no action has been taken yet on this application.

To open the form click on the 'Modification of Application'. Figure-3 shows that form

Figure-4 shows the screen; search the application by giving e-Disha transaction Id, Name or Date of application.

After filling one or all fields, click on 'Search' button, search result will be shown on the same page as given below. For any particular record, click on the 'Edit' button to modify the record.

Search and Print: This page is to search and print the details of any of the service of Revenue court cases (view case Status or view cause list or view judgment) that the user has registered for.

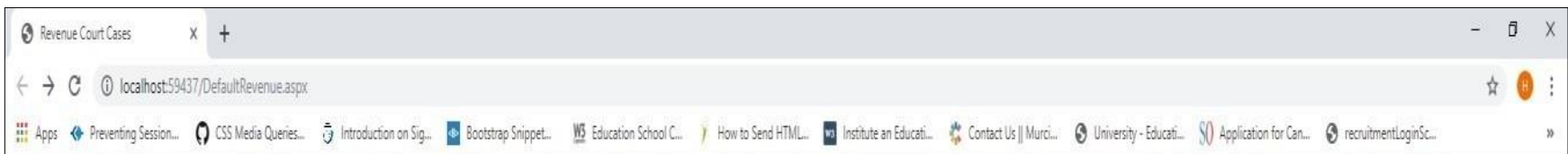

\section{Revenue Court Cases - Justice Delivery System}




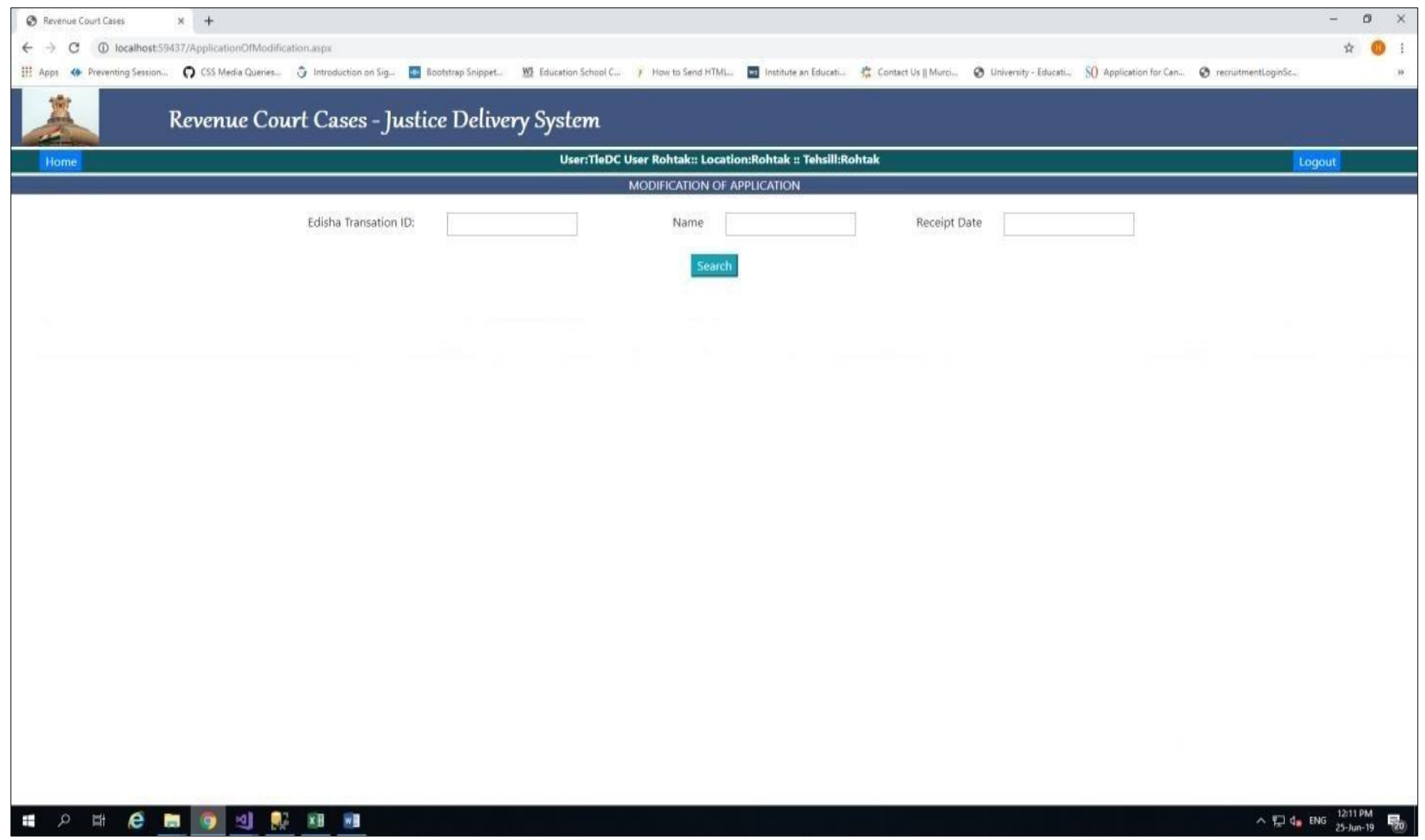

Figure-4 Search Portal

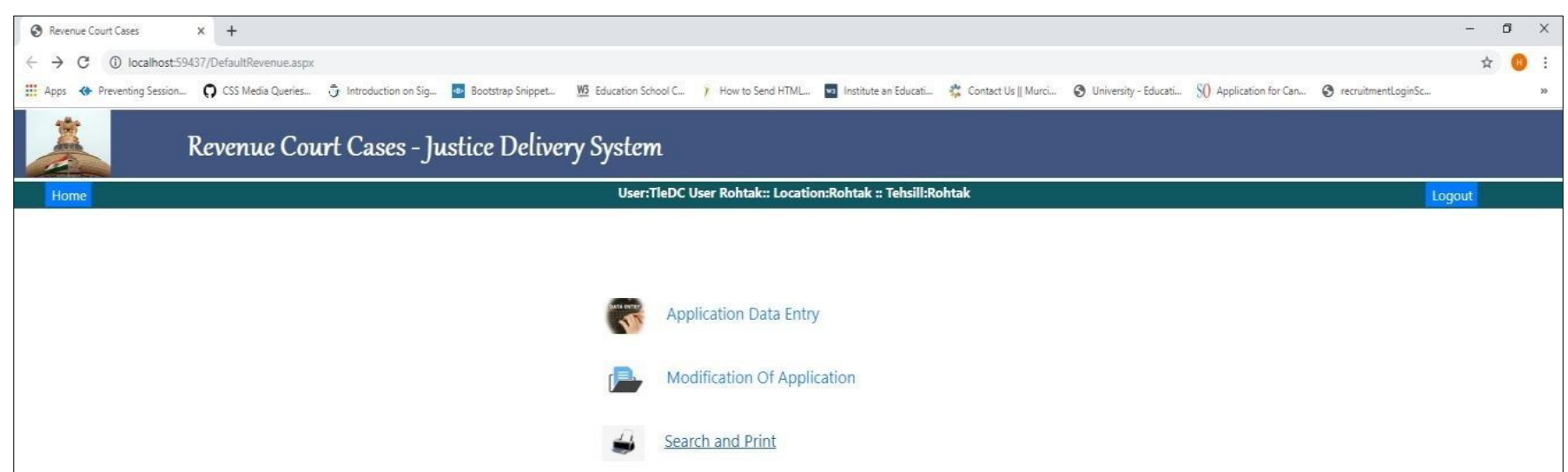

Figure-5 Search and Print Screen

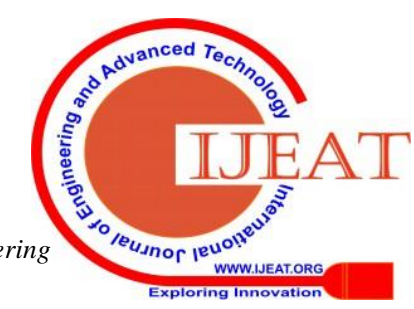


In the search screen, enter Transaction id to search the record. After that click 'search' button, the user is presented with the form according to the service he has registered for.

In the resulting window user can search and print the case status.

Highlights of this solution are:

- One window for all the queries that includes application, modification and searching.

- User-friendly as the form is very simple, short and easy going. No complexities are there in any of the field.

- Mode of payment is available in both cash and draft which has made the system convenient.

- Viewing Case Status is more informative with fewer steps involved.

- By just entering e-Desha Transaction ID, searching of any record can be done in one click.

- No chance of imposter as every step is verified with proper authentication.

- Extra personal details are not required, only limited fields are accustomed to make the form straightforward.

- Payment mode is completely safe from all type of internet scams.

- Modification of application is no more a multilevel task as now it became a single-step task.

\section{REFERENCES}

1. Digital Land (Comprehensive System of Land Management) https://nceg.gov.in/sites/default/files/case_studies/Digital_Land.pdf

2. Comptroller and Auditor General of India Supreme Audit Institution of India

https://cag.gov.in/content/report-no1-2019-revenue-sector-governmen trajasthan

3. RCMS in MP

http://www.aiggpa.mp.gov.in/images/files/pdf/Revenue $\% 20$ Case $\% 20$ Management $\% 20$ Services\%20(RCMS)\%20in\%20Madhya\%20Prades $\mathrm{h} \% 20 \% \mathrm{E} 2 \% 80 \% 93 \% 20 \mathrm{An} \% 20$ appraisal.pdf

4. Digital India Land Records Modernization Programme: Assessing impact in Himachal Pradesh and Maharashtra https://ideasforindia.in/topics/miscellany/digital-india-land-records-m odernisation-programme-assessing-impact-in-himachal-pradesh-andmaharashtra.html

5. Daksh-access-to-justice-survey.pdf http://dakshindia.org/wp-content/uploads/2016/05/

6. 'Digital Land' boosts Uttar Pradesh 'Bhulekh' https://expresscomputer.in/egov-watch/digital-land-boosts-uttar-prade sh-bhulekh/33591/

7. Rural Punjab goes Digital https://worldbank.org/en/news/feature/2017/02/06/rural-punjab-goesdigital

8. Government of Punjab , India https://worldbank.org/en/news/feature/2017/02/06/rural-punjab-goesdigital

9. ePay-final-User-manual.pdf https://ecourts.gov.in/ecourts_home/static/manuals/ePay-Final-USermanual.pdf 